Joanne Stolk

\title{
Combining Linguistics, Paleography and Papyrology: The Use of the Prepositions eis, prós and epí in Greek Papyri
}

\begin{abstract}
The prepositions eis, prós and epí alternate with the plain dative case to express an animate goal of motion and transfer verbs in Greek. The preposition eis 'to' is commonly used for inanimate goals and to express 'on account of what/whom' a payment is made, prós 'to' is used for the transfer of an animate object to an animate goal and epí 'for' to express a special purpose of sending for someone. Exceptions to these general tendencies merit closer examination of the paleographical and linguistic context. In this paper, I provide several new interpretations, translations and readings of exceptional usages of these prepositions in Greek documentary papyri from Egypt.
\end{abstract}

Keywords: Greek linguistics, Greek papyrology, paleography, prepositions, dative alternation

\section{Introduction}

In a previous study (Stolk 2017), I analyzed various ways of expressing the human goal of motion and transfer verbs in Greek papyrus letters from Egypt (300 BC $400 \mathrm{AD}$ ), comparable to the alternation between 'I send you a letter' and 'I send a letter to you' in English. In Postclassical Greek, the preposition prós with accusative is used to express the animate (i.e. human) goal of motion verbs (1) and for transfer of an animate object to an animate goal (see section 3 below), alternating with the plain dative case in these constructions (Stolk 2017: 218-225). The dative case is the default argument realization for the animate goal of transfer of an inanimate object (2), and with verbs of communication (3) and giving (4). 
(1) (PSI IV 341, 4-5; Philadelpheia, 256 BC) ${ }^{1}$

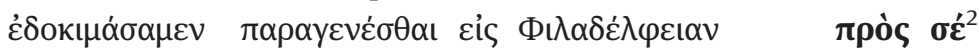

edokimásamen paragenést ${ }^{h}$ ai eis $P^{h}$ iladélp ${ }^{h}$ eian prós Sé

approve:1PL come.INF to Philadelpheia.ACC.SG to 2sG.ACc

'we decided to come to Philadelpheia to you'

(2) (P.Tebt. II 424, 2; Tebtynis, late 3rd ct. AD)

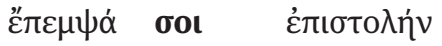

épempsá soi epistolên

send.1SG 2sG.DAT letter.ACC.SG

'I sent you a letter'

(3) (P.Thomas 14, 3-4; Karanis, 2nd half 2nd ct. AD)

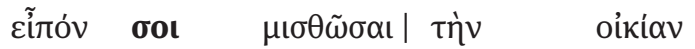

ê̂pón soi mist ${ }^{h} \hat{s} a i$ tèn oikían

tell.1SG 2sG.DAT let.INF DEF.ACC.SG house.ACC.SG

'I told you to let the house'

(4) (P.Brem. 51, 14-15; Hermopolis, 113-120 AD)

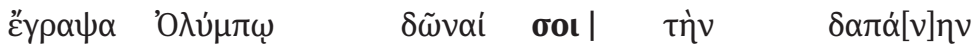

égrapsa Olúmpōi dônaí soi tèn dapánēn

write.1SG Olympos.DAT.SG give.INF 2sG.DAT DEF.ACC.SG expenses.ACC.SG

'I wrote to Olympos to give you the expenses'

Besides the preposition prós and the dative case, several other prepositions, such as eis and epí, can be used in the constructions illustrated in examples (1)(4) above. Although the prepositions became largely synonymous in Medieval and Modern Greek (Bortone 2010: 208-210), their individual uses can still be distinguished in Postclassical Greek (Stolk 2017: 217-218, 226-228). For example, the preposition eis is generally used to express an inanimate (i.e. non-human) goal of movement, such as a place name or location, in Classical and Postclassical Greek (Luraghi 2003: 107-109; Mayser 1934: 408), e.g. 'I send him to London', cf. eis Philadélpheian 'to Philadelpheia' in example (1). Most

1 Papyrus editions are cited according to the Checklist; metadata are based on the information available in TM and the HGV (accessible through the PN).

2 The Greek text is taken from the Papyrological Navigator (PN) and checked against the editio princeps (ed.pr.) and the Berichtigungsliste (BL). Transliteration, basic glosses and translation are provided; translations are my own but may be based on the edition of the ed.pr. 
attestations in documentary papyri confirm this tendency, but there are some exceptional cases, such as example (5).

(5) (SB VI 9121, 12-13; Arsinoite, ca. 31-64 AD)

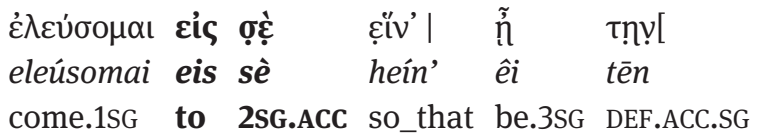

Ed.pr.: 'I will come to you in order that (?)'

This papyrus contains the preposition eis 'to' followed by an animate goal, namely the personal pronoun sé 'you'. Apart from the prepositional phrase eis sé 'to you', the following words (interpreted as heín' êi tèn by the first editor) do not make much sense either. Dots under some of the letters indicate that part of the reading is uncertain and may need revision. ${ }^{3}$ Finally, many years after its first edition in 1951, the reading of this phrase was corrected into eleúsomai eis Arsinoêtēn 'I will come to the Arsinoite' by Litinas (2013: 312), providing the expected inanimate goal (i.e. the Arsinoite district in Egypt) after the preposition eis 'to'. In this case, the problematic reading of the first edition was adapted after close inspection of the contents of the papyrus by Litinas. Similar problems, however, could be identified during a linguistic study into the usage of prepositions in papyri. ${ }^{4}$

In this paper, I explore the potential of this interaction between linguistics, paleography and papyrology in more detail on the basis of the prepositions eis 'to' (section 2), prós 'to' (section 3) and epí 'for' (section 4). Each of those three prepositions can be used in the papyri to express the goal of motion or transfer, besides the plain dative case. In section 2, I first illustrate the semantic distinction between the use of the dative case and the preposition eis 'to' with animate goals, before suggesting an alternative reading for another problematic example of eis 'to'. After close study of the use of the remaining two prepositions in the papyri, I propose two more examples for which the reading of the

3 The critical signs used in papyrus editions are in accordance with the so-called "Leidener Klammersystem" (Van Groningen 1932). Text between square brackets [ ] is not preserved on the papyrus, but supplemented by the editor; a dot under a letter signifies an uncertain reading; text between pointed brackets $<>$ is added by the editor; between curly brackets \{\} is removed by the editor and between double square brackets $\llbracket \rrbracket$ means that it was removed by the scribe.

4 This example also shows that one has to be careful with uncertain readings. At the same time, it is important to keep track of corrections provided to previously edited papyri. Since 1913, the BL collects the corrections in interpretation and reading of all published papyri from secondary literature. The digital editions in the PN offer an opportunity to integrate older and newer corrections immediately in the online version of the text. However, this is an on-going process which relies on the support of all scholars working with papyri. 
preposition eis 'to' should be changed, respectively into prós 'to' (section 3) and epí 'for' (section 4). My main aim is to show how linguistic exceptions could provide a starting point to improve philological interpretation.

\section{The Preposition eis 'to'}

The preposition eis 'to' with the accusative case is generally used for motion and transfer to an inanimate goal in Greek (cf. discussion in section 1). However, there is a special meaning of eis 'to' in the papyri which can be used both for human and non-human goals of transfer, namely the expression 'on account of whom' a payment shall be made. This usage is frequently attested in accounts in documentary papyri (Mayser 1934: 356-357). Mayser (1934: 356 fn. 1) remarks about this usage that "it should be noticed explicitly that in many cases the paraphrase with eis is not in complete agreement with the real dative" (my translation). The difference between the preposition eis 'to' and the plain dative case as recipient can be observed in example (6).

(6) (P.Cair.Zen. IV 59647, 49-51; Philadelpheia, before 248-247 BCE; Mayser 1934: 356 fn. 3)

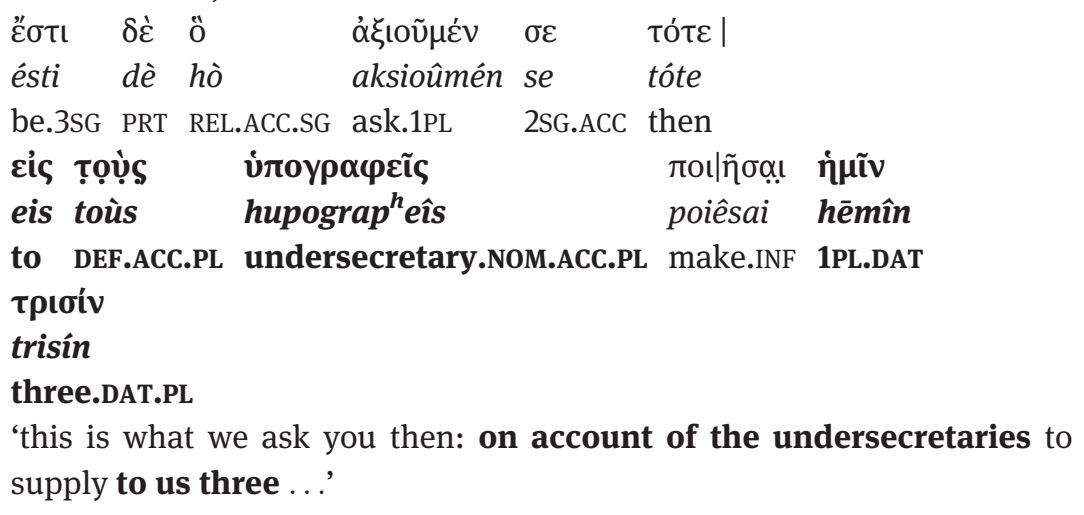

The intended beneficiaries of the payments are first expressed by a prepositional phrase, eis toùs hupografeís 'to the undersecretaries', later referred to by the dative hēmîn trisín 'us three'. The editor, C. C. Edgar, commented that "the

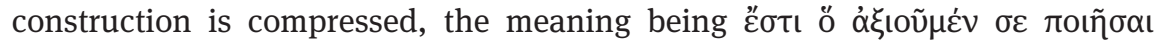

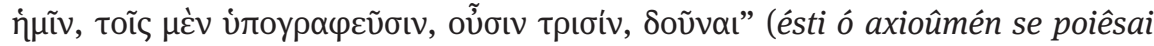
hēmîn, toîs mèn hupograp ${ }^{h}$ eûsin, oûsin trisín, doûnai 'this is what we ask you to supply to us [dative], the undersecretaries [dative], being three [dative]'). In 
fact, there is no need to change all elements into the dative case, as the editor seems to suggest, in order to understand the message. In my opinion, the above formulation perfectly illustrates the difference between the prepositional phrase related to the topic of payment 'on account of the undersecretaries' and the following real recipients of the salaries 'supply to us three, to the one ..., to the others ...' in the dative case. Similar extensions from concrete to abstract direction can be found in Classical Greek referring "to a human landmark with respect to whom an action is performed” (Luraghi 2003: 114). This usage may seem to come close to the semantic role of beneficiary, but it also occurs with inanimate landmarks (Luraghi 2003: 113-115). There is no essential difference, though, in payments 'regarding the office' or 'regarding the secretaries', both conceptualized as an abstract direction of payment rather than a concrete (and animate) beneficiary or recipient of the performed action.

Still, there remain a few instances of the use of the preposition eis 'to' with human beings which do not fit this semantic interpretation either. One of those problematic instances is found in the private letter in example (7).

(7) (SB XIV 12027, 4-5; unknown provenance, 2nd-3rd ct. AD)

\begin{tabular}{|c|c|c|c|}
\hline 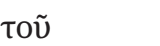 & 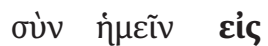 & 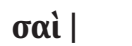 & $\kappa \alpha \tau \alpha \pi \lambda \varepsilon \tilde{v} \sigma \alpha \iota$ \\
\hline toû & sùn hēmeîn eis & saì | & katapleûsai \\
\hline GEN.SG & with 1PL.DAT to & 2SG.ACC & sail_down.INF \\
\hline
\end{tabular}

Just as in example (5), the preposition eis seems used to express an animate goal 'to you' instead of its normal use with inanimate goals, cf. example (1). Since only these last words are preserved of the body of the letter, it is difficult to get a proper understanding of the context. Furthermore, one has to assume an alternative spelling for the accusative case of the pronoun, namely sai for se 'you'. Although variation between $<a i>$ and $\langle e\rangle$ is relatively common in the Roman period (Gignac 1976: 191-193), it is not entirely satisfactory to assume an alternative form in an uncertain context. Even if we accept the reading of eis (the final sigma is not entirely clear) and sai, there seem to be some small traces of one more letter after sai on the photo, possibly a $<n>.^{5}$ A reading such as eis Sáin could provide the expected location, namely 'to Sais'. As a personal name, Sais is rarely attested during the Roman period (see TM Name 7561) and this

5 An image of the papyrus can be found in Sijpesteijn (1971), plate II (after p. 76). For paleographical comparison, one could compare the shape of this letter with for example the $n$ in otan in 1.2 . 
would not solve the problematic use of the preposition eis with an animate goal. However, Sais could also be understood as the name of a city (TM Geo 2072), the capital of the Saite district. ${ }^{6}$ Its location in the Egyptian delta would fit as the destination of a journey sailing downstream.

\section{The Preposition prós 'to'}

The preposition prós ‘to' with the accusative case is used for the animate goal of verbs of motion ('I come to you') and transfer ('I send someone to you'), alternating with the dative case (Stolk 2017: 218-225). There is an important difference between the preposition and the dative case with verbs for sending: the preposition is only used when sending people (8), while the dative case is also used for the sending of inanimate objects (9). This distinction has been shown by Danove (2007) for the use of prós 'to' in the New Testament and the same distribution can be found in papyrus letters (Stolk 2017). The following examples (8)-(9) illustrate the two variant realizations of an animate goal with the same verb for sending.

(8) (P.Mich. VIII 474, 8; Alexandria(?), early 2nd ct. AD)

\begin{tabular}{|c|c|c|c|c|c|}
\hline 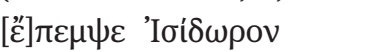 & tòv & vióv & {$[\sigma] \mathrm{ou}$} & $\pi \rho \grave{\varsigma} \varsigma$ & 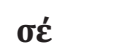 \\
\hline épempse Isídōron & tòn & huión & sou & pròs & sé \\
\hline $\begin{array}{l}\text { send.3SG Isidoros.ACC.SG } \\
\text { 'she sent your(?) son Isidd }\end{array}$ & $\begin{array}{l}\text { DEF.ACC.SG } \\
\text { ros to vou' }\end{array}$ & son.ACC.SG & 2SG.GEN & to & 2SG.ACC \\
\hline
\end{tabular}

(9) (P.Mich. VIII 481, 35; Alexandria(?), early 2nd ct. AD)

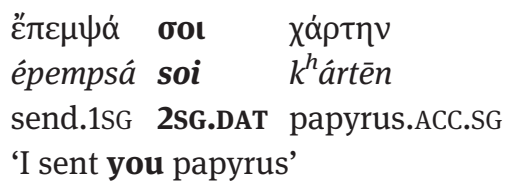

In the first instance, Isidoros is sent (meaning: caused to move) towards a prepositional goal (8), while in the second event the sending of papyrus (meaning: change of possessor) is expressed with a dative case as the endpoint of transfer (9). This difference in meaning could help to solve another problematic instance

6 It is not often attested in papyri from this period; a possible - but equally uncertain attestation can be found P.Strasb. IV 253, 1. 6: 'he has gone to the (city of) Sais'. 
of eis 'to' with a personal pronoun instead of an inanimate goal. Example (10) is attested in a letter of a bailiff to his master Dionysios.

(10) (P.Mert. I 38, 22-27; unknown provenance, mid 4th ct. AD)

\begin{tabular}{|c|c|c|c|}
\hline 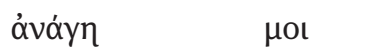 & $\kappa \alpha i ́ v \varepsilon \mid \tau \omega$ & $\dot{\alpha} \delta \varepsilon \lambda \varphi \tilde{\omega} \nu$ & $\mu \mathrm{ov} \mid$ \\
\hline anágè & kaínetō & $\operatorname{adelp}^{h} \hat{o} n$ & mou \\
\hline necessity.NOM.SG 1SG.DAT & become.3SG DEF.GEN.PL & brother.GEN.PL & 1SG.GEN \\
\hline 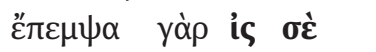 & $\pi \varepsilon \rho \grave{~} \quad \tau o u ́ \mid \tau \omega<\nu>$ & & \\
\hline épempsa gàr is sè & perì toútōn & & \\
\hline send.1SG for to 2sG.AC & CC about DEM.GEN.PL & & \\
\hline 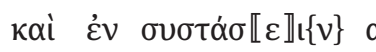 & $\alpha u ̉ \mid \tau \tilde{\omega} \nu \quad \sigma \chi \tilde{\imath} \varsigma$ & Ало $\lambda \lambda \omega{ }^{\prime} \mid \nu t \omega \nu$ & \\
\hline kaì en sustási & autōn $s k^{h} \hat{\imath} s$ & Apollốniōn & \\
\hline and in care.DAT.SG & 3PL.GEN have.2SG To & Apollonios.ACC.SC & \\
\hline
\end{tabular}

The first editors, Bell and Roberts, translate the lines quoted in example (10) as follows: "I had need of my brothers; for I sent to you about them and that you might commend them to Apollonius". The last part of that sentence was reinterpreted by Worp (2000: 190), translating "for I sent (a messenger) to you about them and take care of him with respect to Apollonios”. It is indeed likely that the phrase 'I sent to you' implies the sending of a person delivering the message. ${ }^{7}$ Furthermore, it seems that this person who is sent to the landowner Dionysios is the same as the person who needs to be recommended to Apollonios. $^{8}$ This type of sending of a person to an animate goal would

7 The contents of that message are likely to concern his brothers, but that does not mean that we need to translate the topic peri toútō<n> as 'about them'. In both previous translations, the personal and demonstrative pronouns in this part of the letter are understood to refer to persons: both to the brothers in the first edition; the demonstrative pronoun toutō to the brothers and the personal pronoun autôn to the messenger (by understanding the genitive plural autôn as standing for an accusative singular autón) in Worp (2000: 190). However, the scribe seems to distinguish between the two types of pronouns in other parts of the letter (cf. 1l. 6-8, 13). In my opinion, there is no need to understand peri toútō in $11.24-25$ as anything else than a demonstrative pronoun referring to the contents of the letter 'about these things'; compare the personal pronouns 'their' and 'them' in 11.6 and 7, next to same phrase peri toútōn translated as "about that" in 1.8 of the edition.

8 This transfers the problem to the interpretation of the object of the next phrase, literally 'to have in care/commendation'. The first editors understood the personal pronoun autôn as a genitive plural 'you have care/commendation of them', but the parallels for the new interpretation suggested by Worp (2000) take an accusative object 'you have him in care / commendation'. Due to 
normally be expressed by the preposition pros, cf. example (8). While Worp (2000: 190) is arguing for a new interpretation of en sustási in the second part of this sentence, he adopts the reading of this remarkable gàr is sé 'for to you' without further comment. Even though there are a few small lacunae at this spot on the papyrus, I would argue to read pròs sé 'to you' rather than gàr is sé 'for to you' here.' The new reading also avoids the assumption that the scribe spelled is instead of eis only here, while he writes eis elsewhere in the letter (ll. 14, 17 and 21).

\section{The Preposition epí 'for'}

The preposition epí 'for' with the accusative case can be used for motion or transfer towards an inanimate or animate goal in papyri. ${ }^{10}$ Apart from the neutral motion towards a goal (1934: 476-479), Mayser (1934: 480-482) distinguishes a final use in which the preposition expresses the purpose of movement, i.e. "the object or purpose for which one goes” (LSJ s.v. III.1). Already in Homeric and Classical Greek, the preposition epí can have this metaphorical meaning to express the purpose of an action, although epi with accusative is limited to inanimate landmarks in Homer (Luraghi 2003: 307-308). In Classical Greek, epí with accusative for animate landmarks often takes the role of maleficiary (Luraghi 2003: 312-313). In private letters from the Roman period, epi with accusative is

the frequent interchange of omicron and omega in this letter (see e.g. the name Apollôniōn in 11. 26-27 which is declined as a genitive plural while it should be understood as the accusative singular Apollōnion), it would be possible to understand the genitive plural autôn 'them' as an accusative singular autón 'him'. The accusative singular would mean that just one person is recommended and this could be the same person that is implied in the sending. If the brothers are indeed to be understood in plural in 1.23 , the text seems to say that a message about them is delivered by just one person and that this (to us unknown) messenger is the one who needs to be introduced to Apollonios.

9 An image can be found in the edition P.Mert. I, plate XL. The upper part of the pi is rounded (in contrast to the classic three-stroke pi in épempsa) and, because of that, the editors may have thought of a combination of gamma and alpha. However, the pi of prós two lines below is also rounded and the space before the following rho seems too narrow for an alpha in this hand. The small trace coming out of the lacuna afterwards could fit almost any small letter, but the space and height seem more than adequate for an omicron.

10 For the seemingly free variation between cases used with epi 'for' and the prepositions en 'in' and eis 'to' with an accusative (inanimate) goal of motion in Hellenistic-Roman Greek see Skopeteas (2008); for the merger of en 'in', prós ‘to', epí ‘for' and eis ‘to' in Medieval Greek see Bortone (2010: 208-210). 
commonly used to express the purpose of movement with animate referents, see examples (11) and (12).

(11) (BGU VII 1676, 9-11; Philadelpheia, 2nd ct. AD)

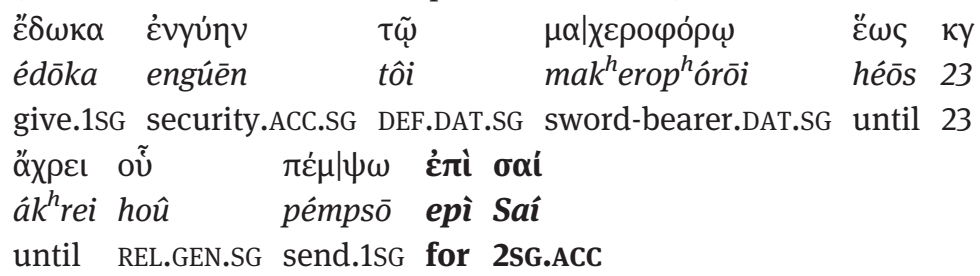

'I gave security to the sword-bearer till the 23rd to give me time to send for you'

(12) (P.Fay. 135, 5-7; Euhemeria, 4th ct. AD)

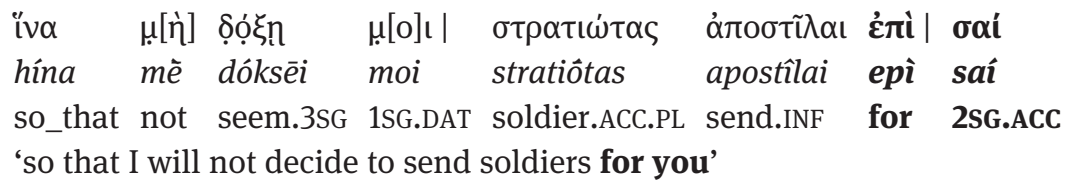

In example (11), the subject Sarapodoros is not just sending someone to his friend Phaneion (which would have been expressed with the preposition prós 'to' instead of epí 'for'), but he is sending someone to fetch Phaneion. A similar situation occurs in example (12). The subject, Agathos, warns his father that he will have to send soldiers after him to get him and put him in prison, if he does not pay now. In both letters, the prepositional phrase with epí 'for' does not express the endpoint of motion, but the purpose of sending: to fetch the person sent for. ${ }^{11}$

The same meaning denoting the purpose of one's own travelling is attested with verbs of going; ${ }^{12}$ see example (13).

11 This purposeful 'sending for someone' is already attested in Classical Greek: 'for it was Cyrus who sent to Amasis for (epi + accusative) his daughter (to marry him)' (Herodotus, Histories 3.2.1; Luraghi 2003: 313, example 55). Other examples in the papyri are found in SB XIV 12034, 13 (Upper Egypt, 175 AD) and perhaps O.Claud. II 293, $13-14$ (Mons Claudianus; ca. 142-143 AD).

12 Other examples with a verb of going in the papyri are found in PSI XIV 1404, 11-17 (unknown provenance, 41-42 AD) with BL 4, 92 and 11, 251; P.Paris 18, 9 (unknown provenance, 3rd ct. AD); P.Ant. I 43, 21-23 (Antinoite, late 3rd-4th ct. AD), although the interpretation and use of prepositions in this text is puzzling; and perhaps SB X 10476, 6 (unknown provenance, 5th-6th ct. AD). 
(13) (P.Mich. XV 750, 17-19; unknown provenance, 19.11.172 BC)

\begin{tabular}{|c|c|c|c|c|}
\hline 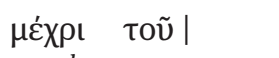 & $\pi \alpha \rho \alpha y \varepsilon v \varepsilon ́ \sigma \theta \alpha \iota$ & $\mu \varepsilon \mid$ & $\dot{\varepsilon} \pi \grave{~} \sigma \dot{\varepsilon}$ & бuvтó $\mu \omega \varsigma$ \\
\hline mek $^{h} r i$ toû & paragenést $^{h} a i$ & me & epì sè & suntómōs \\
\hline $\begin{array}{l}\text { until DEF.GEN.SG } \\
\text { 'until I come for yo }\end{array}$ & $\begin{array}{l}\text { come.INF } \\
\text { ou shortly' }\end{array}$ & 1SG.ACC & to 2SG.ACC & shortly \\
\hline
\end{tabular}

The letter, possibly from a husband to his wife, explains that he cannot come to her right now and he is not able to send her anything. Sijpesteijn, the editor, translates the last lines of the letter as follows: "Please look after yourself until my forthcoming arrival. Secure your things as you'll be moving with us" (p. 129). The prepositional phrase epí sé 'for you' is only translated implicitly in "until my forthcoming arrival”, namely 'to you, at your place'. However, epí with accusative does not generally express arrival at a certain location. ${ }^{13}$ The above mentioned special meaning of epí expressing the reason for coming, namely to fetch someone, would make more sense in this situation. That her husband is not just travelling to her, but will come to fetch her, becomes clear in the following sentence: “as you'll be moving with us". In this instance, a slightly different translation, such as 'until I come for you shortly', provides a more coherent interpretation of the event described.

The special meaning of the preposition epi would also be suitable for the situation described in the following letter from Theon to his father; see example (14).

(14) (P.Oxy. I 119, 11. 13-14; Oxyrhynchos, 2nd-3rd ct. AD)

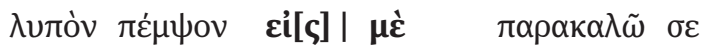

lupòn pémpson eis mè parakalō se

then send.IMP to 1SG.Acc beg.1SG 2SG.ACC

'then, send for me, I beg you'

Again, we find the preposition eis 'to' used with an animate goal 'you'. The first editors, Grenfell and Hunt, read lupón 'then' as lúron 'lyre:ACC.SG' and thought that Theon asked his father to send a lyre to him. This reading was corrected by Wilamowitz into lupón as misspelling for loipón 'then' (P.Oxy. II, p. 320), but this also removes the object of the sending, resulting in translations such as

13 For the locative meaning of epí + dative see Rodríguez Somolinos 2013. A motion verb combined with a locative sense of the preposition epí 'upon' is found in the bilingual Latin-Greek letter P.Oxy XVIII 2193, 7 (Oxyrhynchos, late 4th - early 5th ct. AD) 'the most holy hortatory word has come upon you', possibly because the language of this letter was influenced by biblical sources, cf. e.g. Luke 11.20: 'the kingdom of god has come upon you (pl.)', see ed.pr. n. to 1. 7. 
“so, send me (something good), I beg you" (Humbert 1930: 181; my translation). Even assuming an implicit object, we would still expect the sending of an inanimate object ("something good") to an animate goal to be expressed with a plain dative case or the sending of an animate object ('send someone to me') with the preposition prós (see section 3 above). A young boy is writing this letter to his father begging him to take him on his journey to Alexandria. Unfortunately, his father has already left and it seems that the only way in which he could still join his father in Alexandria is by sending someone down to fetch him. Winter (1933: 60), therefore, translated the phrase as "send for me". As we have seen above in examples (11)-(13), the meaning 'send for me (to fetch me)' is denoted by the preposition epí in other letters from this period. The preposition ei[s] 'to' is written at the end of the line and the final letters have been damaged. Reading ep[i] instead of ei[s] seems unproblematic. ${ }^{14}$ The only problem to this reading is posed by the weak form of the 1st personal singular pronoun (me) at the beginning of the following line. In contrast to the 2nd person singular, Greek distinguishes between weak and strong forms of the oblique cases of the 1st person singular pronoun. Usually, the strong form (emé) is preferred after prepositions, except after the prepositions eis 'to' and prós 'to' which also occur with weak forms (Gignac 1981: 161-162). If the young boy indeed followed these rules, the most likely supplement would be $e p$ ' [e]|me 'for me'. The word boundary through the personal pronoun may be unproblematic, as he breaks several words in the preceding sentences in a similar way, e.g. elpistolên 'letter' in $11.4-5$. Both the reading and meaning of the preposition epí 'for' fit the context better than eis 'to'.

\section{Conclusion and Discussion}

Papyrus editions are not only useful sources for linguistic research, but, as I argue in this paper, linguistic research can also be beneficiary for papyrus editions. Apparent exceptions to linguistic theories may be explained by different interpretations, such as the new explanations and translations proposed for examples (6) and (13). Others can be understood by providing a new reading that fits both the paleographical traces and the linguistic context, such as examples (5), (7), (10) and (14).

14 An image of the papyrus can be found in Parsons (2007), plate 26 (after p. 194). The little hook to the left at the bottom of the second letter seems more fitting for a pi than an iota and even a small trace of the second leg of the $p i$ is visible at the edge of the lacuna. 
This approach is not without perils. In the first place, I would strongly argue against just altering the reading of the edition in order to fit a linguistic theory. Correction of a reading should always be based on paleography in the first place, besides other considerations. On the other hand, one has to accept that editing a papyrus is often a combination of understanding the language and reading the traces. Ultimately, what is written on the papyrus itself should form the basis for linguistic studies and not a (wrong) interpretation by the first editor. Therefore, corrections of readings should be possible, also in linguistic studies.

In the Handbook of Papyrology, Schubert (2009: 212-213) describes the editing of papyri as "an evolving process" of reading, misreading, correction and reinterpretation, often prompted by newly published papyri and studies about the cultural and historical context:

"documents on papyrus display a regularity that makes papyrologists beware of exceptions. If these occur, they should be justified as far as possible. Unparalleled personal names, grammatical oddities, and geographical and chronological inconsistencies should alert a reader to the possibility of an erroneous reading. The process of editing a papyrus therefore never ends."

In this paper, I hope to have shown that linguistic studies can make a valuable contribution to this continuous process of reading and interpreting Greek documentary papyri.

Acknowledgements: I would like to thank Anastasia Maravela, Willy Clarysse, Mark Janse and two anonymous reviewers for their comments to earlier versions of this paper. My research was funded by the Research Foundation Flanders (FWO) and The Research Council of Norway (NFR) and carried out at Ghent University and the University of Oslo.

\section{Abbreviations}

The glosses follow Leipzig Glossing rules, accessible at www.eva.mpg.de/lingua/ pdf/Glossing-Rules.pdf. Additionally, the following gloss have been adopted: PRT - particle

Papyrus editions are cited according to the Checklist = Oates, John, William Willis et al. Checklist of Editions of Greek, Latin, Demotic, and Coptic Papyri, Ostraca, and Tablets, accessible at www.papyri.info/docs/checklist.

BL Preisigke, Friedrich, et al. 1913-2017. Berichtigungsliste der Griechischen Papyrusurkunden aus Ägypten. Band I - XIII. Leiden: Brill. 
HGV Heidelberger Gesamtverzeichnis der griechischen Papyrusurkunden Ägyptens at http://aquila.zaw.uni-heidelberg.de

LSJ Liddell, Henry George \& Robert Scott, revised by Sir Henry Stuart Jones. 1996. A Greek-English Lexicon. Oxford: Clarendon.

PN Papyrological Navigator at www.papyri.info

TM Trismegistos at www.trismegistos.org

\section{References}

Bortone, Pietro. 2010. Greek Prepositions: From Antiquity to the Present. Oxford: University Press. Danove, Paul. 2007. Distinguishing Goal and Locative Complements of New Testament Verbs of Transference. Filologia Neotestamentaria 20. 65-80.

Litinas, Nikos. 2013. The Expressions "to Annoy" as Used in Alexandria and "to Sit on a Donkey”. Chronique d'Égypte 88 (176). 307-312.

Gignac, Francis Thomas. 1976. A Grammar of the Greek Papyri of the Roman and Byzantine Periods, Vol. 1: Phonology. Milano: La Goliardica.

Gignac, Francis Thomas. 1981. A Grammar of the Greek Papyri of the Roman and Byzantine Periods, Vol. 2: Morphology. Milano: La Goliardica.

Groningen, Bernard A. van. 1932. Projet d'unification des systèmes de signes critiques. Chronique d'Égypte 7. 262-269.

Humbert, Jean. 1930. La disparition du datif en grec (du ler au Xe siècle). Paris: Édouard Champion.

Luraghi, Silvia. 2003. On the Meaning of Prepositions and Cases: The Expression of Semantic Roles in Ancient Greek. Amsterdam \& Philadelphia: Benjamins.

Mayser, Edwin. 1934. Grammatik der griechischen Papyri aus der Ptolemäerzeit, Vol. II 2: Satzlehre, Analytischer Teil 2. Berlin: De Gruyter (1934).

Parsons, Peter. 2007. City of the Sharp-nosed Fish: Greek Lives in Roman Egypt. London: Weidenfeld \& Nicolson.

Rodríguez Somolinos, Helena. 2013. What Does émí Really Mean? Contact and Dimensionality of the Landmark as Basic Semantic Categories in the Locative Prepositional Phrases with ह̇iń. Journal of Latin Linguistics 12 (2). 199-230.

Schubert, Paul. 2009. Editing a Papyrus. In Roger S. Bagnall (ed.), The Oxford Handbook of Papyrology, 197-215. Oxford: Oxford University Press.

Sijpesteijn, Pieter Johannes. 1971. Fragments of Letters from the Amsterdam Papyrus Collection. Talanta 3. 74-82.

Skopeteas, Stavros. 2008. Encoding Spatial Relations: Language Typology and Diachronic Change in Greek. Language Typology and Universals 61. 54-66.

Stolk, Joanne. 2017. Dative Alternation and Dative Case Syncretism in Greek: The Use of Dative, Accusative and Prepositional Phrases in Documentary Papyri. Transactions of the Philological Society 115 (2). 212-238.

van Groningen, Bernard A. (see Groningen)

Winter, John Garrettt. 1933. Life and Letters in the Papyri. Ann Arbor: University of Michigan Press.

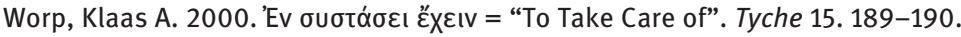

